DOI: 10.2478/auseur-2019-0014

\title{
Cultural Ties between Hungary and India. A Short Overview
}

\section{Dezső SZENKOVICS}

$\mathrm{PhD}$, Sapientia Hungarian University of Transylvania (Cluj-Napoca, Romania) Institute for Foreign Affairs and Trade, Budapest, Hungary

e-mail: szenkovics@kv.sapientia.ro

\begin{abstract}
The interest of the Hungarians towards Asia is deeply rooted in the historical fact that the ancestors of the Hungarian nation arrived in their present country from the East. Over the centuries, this historical fact has significantly determined the interest and openness of the Hungarian people towards the East. In spite of the fact that the Hungarian people did not belong to the European colonizers, during the centuries, a large number of Hungarian travellers (monks, artists, scholars, and nobles) reached the coasts of India and contributed to the spread of Indian religions, literature, languages, arts, etc. in Europe.
\end{abstract}

Keywords: Hungary, India, cultural ties

\section{Introduction}

In spite of the fact that Hungary and India are closely linked to each other by many ties, ${ }^{1}$ I think that one of the most important and successful connections is realized through culture. This is partly due to the fact that cultural ties are the oldest type of connection in the bilateral relations between the two countries; on the other hand, it is the result of the fact that over the last centuries the two countries have displayed an honest and open interest towards each other's culture, devoid of all hidden agendas. His Excellency, the former Ambassador of India in Budapest, Mr. Gauri Shankar Gupta expressed the same opinion in an interview, declaring that: 'Indian-Hungarian relations can be qualified as extremely fruitful. They continue to strengthen, especially in the area of culture' (Orsós 2011: 24). ${ }^{2}$

Still, in spite of the fact that this connection has a history of several centuries, and although the last decades have been characterized by many intensive and

1 I refer here to the existing diplomatic, economic, commercial, foreign policy, or even military co-operations between the two countries.

2 This citation and the following ones were translated from Hungarian into English by the author. 
flourishing co-operations, no comprehensive work to document the entire era has yet been written. There are written documents, longer or shorter studies, summaries, memoirs, but most of these carry out the documentation of only one actor, event, genre, or period. Perhaps the most comprehensive work in this field is the volume edited by Géza Bethlenfalvy and Ildikó Puskás, entitled India magyar szemmel [India with the Eyes of Hungarians] and published with the support of the Embassy of the Republic of India in Hungary in 1987, in the year of the $40^{\text {th }}$ anniversary of the independence of India. An interesting feature of the volume is that its introductory greetings were written by Rajiv Gandhi, the Prime Minister of India, while its Preface was signed by Satinder K. Lambah, the Ambassador of India at the time. From the thoughts of the former Prime Minister, it is worth quoting the one expressing appreciation for the Hungarian-Indian relations:

Hungarian Indology has great traditions. It was no accident that many Hungarian scholars chose India as their new homeland, wishing to know it better. Three among them - Sándor Körösi Csoma in the $19^{\text {th }}$ century, Erzsébet Sass Brunner and Károly Fábri in our days - are buried in Indian soil. However, even before the journey to India of Sándor Kőrösi Csoma, famous Indian works were translated into Hungarian. The visit of Rabindranath Tagore to Hungary in 1926 further deepened and enriched our relations. And the famous painter of India, Amrita Sher-Gil, was born to a Hungarian mother. (Bethlenfalvy-Puskás 1987: 3)

The volume in question has merits and imperfections as well as intriguing parts. Among its merits, I would like to highlight that - even if only extremely summarily - it attempts to give a comprehensive picture of bilateral relations, including economic, cultural, and scientific ones. Yet it becomes quite apparent upon scrolling through the book for the first time that cultural relations are significantly predominant. Among its deficiencies, I would mention that the book itself was born in an age that was rather marked by socialist ideology. And we must not forget that over 30 years have passed since its appearance, which have been extremely rich with respect to Hungarian-Indian relations. I find it interesting in the volume that János Kádár himself, the former General Secretary of the Hungarian Socialist Workers' Party, commemorates Indira Gandhi, the second Prime Minister of free India. I think that this fact tells quite a lot about the spirit of the publication, for which the two editors are obviously not to be blamed.

Except for this volume, only one other book appeared in the Hungarian language in this subject, entitled Jöttem a Gangesz partjairól. Bengáli kultúra és magyar irodalom [I Came from the Banks of the Ganges. Bengalese Culture and Hungarian Literature], hallmarked by the name of Indologist Imre Bangha. Its great merit is that, following a thorough research carried out with the greatest circumspection 
for many years, it gives a detailed and comprehensive picture of HungarianBengalese relations, mostly in the area of literature but not exclusively. The 550 pages of the work include studies written with scientific accuracy, a part being about Hungarian travellers to Bengal, a chapter dealing with the cult of Tagore as well as literary documents. The volume published at L'Harmattan in 2011 ends with a very thorough and valuable bibliography. However, it is important to underline that this volume does not cover the whole spectrum of HungarianIndian cultural relations as it is only restricted to Hungarian-Bengalese relations.

Two publications in English also appeared. The common feature of these volumes is that they both came out in India, mostly in the same period. The first edition of the publication entitled India and Hungary. Decades of Cooperation, edited by György Kalmár and István Major, appeared in 1979, being republished in 1983. The other volume is the work of Géza Bethlenfalvy, and it is entitled India in Hungarian Learning and Literature, which came out in 1980. Both publications are important from the perspective of researching Hungarian-Indian relations as they summarize well the events in a given era that are important for the research topic. The publication signed by Géza Bethlenfalvy identifies four relevant periods: the Beginnings, the period of Widening Interest, the era of Individual Achievements and of New Vistas (Bethlenfalvy 1980). Still, both volumes only follow the connections between the two cultures until the end of the 1970s.

Besides the mentioned four volumes, numerous studies, essays, articles, and analyses deal with the relations between the two countries, appearing over the years and decades in daily and weekly papers, in professional periodical publications, or on the Internet, covering a narrow segment or commemorating an anniversary or an event.

The present study attempts to provide a comprehensive picture of HungarianIndian cultural relations. At the same time, it can also be perceived as a first moment of a longer-term research. It is no secret that, besides processing existing specialist literature and archive data available for research, my intention is to complete this study in the future with a part that consists of interviews as well as additional information, data, and stories obtained from persons actively shaping Hungarian-Indian cultural relations in the past 40 years (diplomats, employees of foreign representations, researchers, and university staff).

I consider it important to share two further dilemmas. The first dilemma is related to the definition of the term 'culture'. As it is known, culture has quite a number of definitions, some interpreting it more narrowly, while others see it in a wider sense, comprising all the things that the expression can refer to. I operate with a wider notion of culture, characteristic of social scientists. Accordingly, I classified into the notion of culture all human activities and creative processes that generate new values in the end. I think that a wider definition of culture is needed for the more comprehensive presentation of the subject we are dealing with. 
The other great dilemma is connected to the structuring, the construction of the present paper. After long deliberations, I concluded that perhaps the most useful approach from the perspective of the topic would be to divide the time range covering the subject into periods and apply this periodization in the structure of the paper as well. Thus, I tried to identify the important moments that can be considered milestones, turning points in the evolution of the relations between the two countries. After some considerations, I found a division of five periods most adequate. I see the first period as one beginning in the $16^{\text {th }}$ century and ending with the death of Sándor Kőrösi Csoma in India because I think that the personality and the oeuvre of Körösi are an important turning point of the Hungarian-Indian relations. I set the end of the second period to the time of the visit to Hungary of Rabindranath Tagore. Reading contemporary notes, articles, and the later opinions and papers dealing with his visit, I concluded that his journey in $1926^{3}$ had a significant influence on the deepening and the evolution of the cultural relations between the two nations.

I see the third period to be defined by Tagore's visit and the time when India gained his independence. The time between November 1926 and August 1947 may seem to be too short at first glance to cover a whole period, yet it must be underlined that subsequent to the birth of free and independent India Hungary established diplomatic relations with the government in Delhi very quickly, ${ }^{4}$ by which cultural relations also stepped into another, much more formal and structured dimension.

I define the fourth period as the one between the date of birth of modern India (1947) and the liberation of Hungary from communism. ${ }^{5}$ I consider this turning point in the history of Hungary outstandingly important from the perspective of Hungarian-Indian cultural relations because diplomatic relations in general and cultural diplomacy and bilateral cultural relations in particular were subject to significant changes in quality as they got rid of burdensome socialist/communist ideology, becoming much freer.

Finally, I must also mention the short period that started in 1990 and that continues today, of which we all are observers and can even be its shapers sometimes.

31913 Nobel Prize winner Rabindranath Tagore partook in a European lecture tour in 1926, during which he also visited Hungary. During his stay in Hungary between 23 October and 12 November, in addition to his official programme, his renewed cardiac problems were treated in the sanatorium of Balatonfüred. A tree planted in Balatonfüred by the poet commemorates this as well as the promenade named after him in 1957 and the bust placed on the promenade, near the commemorative tree in 1956.

4 Hungary established official diplomatic relations with India on 18 November 1948, and very soon, in 1951, it opened its first embassy in New Delhi. In 1959, diplomatic relations were raised to ambassadorial level.

5 The end of communism was in fact brought to Hungary by the declaration of the Republic of Hungary on 23 October 1989. 
Lastly, I wish to emphasize right from the very beginning that the present paper was born without the pretension of completeness. Even if we only were to consider the restrictions regarding its extent, we had to relinquish the idea of providing the reader with a synthesis that could include every aspect of Hungarian-Indian cultural relations, not to mention that we are talking about a research that is just being carried out. Therefore, this text should be seen as just the flashing of the most relevant data and information available for the author.

\section{From the $1^{\text {th }}$ Century to the Death of Sándor Kórösi Csoma (1842)}

One of the possible explanations of the relatively early and intensive interest of Hungarians in the East may reside in the fact that they wished to find their homeland of origin, the former Magna Hungaria, and because of their supposed Eastern origin they most probably felt kinship with the peoples leaving there (Bethlenfalvy n.d., Bangha 2011, Gáthy 1992). It is enough if we think of the journey to the East of Friar Julian, who set out with three other fellow travellers in the $13^{\text {th }}$ century, aiming to seek the ancestors in the East of the first Magyar settlers in Hungary, or of Sándor Körösi Csoma, who travelled later to Central Asia following a similar goal and who died in India.

The period of over three centuries is not short of cultural relations. The first one hundred years were generally characterized by Indian literature and culture reaching Hungary by means of various intermediary languages. The most significant part of the literary works translated into Hungarian became known in the Hungarian language area thanks to the Latin and the German language. The translation of Buddhist and Hindu fables and legends were the most characteristic of this period. The most important ones of those were Ponciánus császár históriája [The History of Emperor Pontianus] translated from German by Gáspár Heltai (1520-1574) and Humajun-namé translated from Turkish into Hungarian by Dávid Rozsnyai (Rosnyai) ${ }^{6}$ (1641-1718), dragoman and scrivener serving in the time of Transylvanian Prince Mihály Apafi. It appeared under the title Horologicum Turcicum and was the translation of the famous Sanskrit-language fable collection, the Pañcatantra ${ }^{7}$ (Bangha 2011). The work was first published only in 1863.

6 Marosvásárhely-born (in Romanian: Târgu-Mureş) Dávid Rozsnyai (1641-1718) spent most of his life in the service of the Turkish Sublime Port as a scrivener and dragoman. The interesting aspect of his career was, however, that he spent most of his service time in the court of the Transylvanian Prince, visiting Constantinople only on rare, exceptional occasions. He translated the work in question during his captivity in Görgény (1678-1681). Later, as the work remained unpublished, he himself made copies of it and sent them to Transylvanian noble families.

$7 \quad$ The Indian Pañcatantra is considered one of the oldest and most famous collections of tales and at the same time one of the most ancient records of Sanskrit literature. Experts think that its 
In the age of the Enlightenment and Romanticism, interest towards the East grew all over Europe. Hungary was no exception. Probably the most beautiful examples to sustain that fact are the work of Mihály Csokonai Vitéz (1747-1786) on Asian poetry ( $A z$ Ázsiai poézisról) and the historiography of Ferenc Verseghy (1757-1922), entitled $A z$ emberi nemzetnek történetei [Histories of the Human Nation], both of which are to a large degree original works (Bangha 2011). Both works are outstandingly important as they guide Hungarian readers to new realms, mostly unknown at the time; therefore, they significantly contributed to knowledge about Indian culture, specifically Indian literature and history.

However, the first Hungarian who had the chance to directly experience India, even if not of his own free will, was György Huszti, who reached the Western shores of India in the 1530s, serving in the army of Ottoman Sultan Suleiman I (the Magnificent). As he was a literate man, he made notes of his experiences and then structured these into a book, which, although it survived the following centuries, ${ }^{8}$ was never published in its full version.

It is only known by just a few that a Hungarian under the name of István Vályi studying theology in the 1750s at a university in the Netherlands was the first one to point out that the Romani language spoken by some of the European Gypsies was of Indian origin (Lakatos 2008, Hancock 2010). ${ }^{9}$ This observation led to the discovery that the Sanskrit language, and Hindi developing from that, belong in fact to the Indo-European family of languages.

Although quite a few other translations of works belonging to written Indian culture appeared in this period, ${ }^{10}$ the most important and remarkably outstanding performance of the era is connected to the name of Sándor Körösi Csoma (17841842). The Székely-Hungarian language scholar set off as a young man to seek the original homeland of Hungarians. After travelling for two and a half years, he reached India. With the results of his research work carried out in the monasteries of Kanam and Phugtal, the royal fortress of Zangla and the Asiatic Society of

original version appeared in the $6^{\text {th }}$ century B.C. The work in question is in fact a collection of fables, originally meant to teach wisdom to the children of Indian rulers.

8 The manuscript remained extant in two copies. The first one bears the title Georgii Huz peregrinatio Hierosolimitana and is dated 10 November 1548. This copy was made by Huszti in Pozsony, and he intended it for Holy Roman Emperor Ferdinand I. The manuscript can be found in the Austrian National Museum. A later, completed copy of the manuscript, written in 1566, can be found in the library of the Vatican (Stepanić 2011).

9 Hancock affirms in the quoted work, based on his own investigations, that - in contrast to what had been widely believed - István Vályi was not the student of the university in Leiden but of the university in Utrecht.

10 The two other Pañcatantra editions, also translated from intermediary languages, are worth mentioning, too. The first one is the translation of Sámuel Pataky, appeared under the title $A$ régi indusok bölcselkedései [The Wisdom of the Old Hindus] in Eger in 1781. This was followed by the translation of András Csehi (Tsehi) and József Zoltán, printed in 1783 in Kolozsvár (in Romanian: Cluj-Napoca) under the title Bidpai és Lokman indiai históriái és költött beszédei [The Indian Stories and Composed Speeches of Bidpai and Lokman]. 
Bengal seated in Calcutta, Sándor Kőrösi Csoma listed his name forever among the researchers of Eastern Asia. As a result of his work of about two decades, sometimes carried out in extremely harsh conditions, the first Tibetan-English dictionary was born as well as a description of the grammar of the Tibetan language, the translations of the texts of Kangyur and Tengyur, ${ }^{11}$ and a terminological dictionary making the understanding of Tibetan Buddhism possible (Sanghasen 1992). By these results and achievements, he gained indisputable merits not only in the area of Tibetology but also in the research of India as, by catalysing Tibetan religious texts and by their translation into English, he significantly contributed to the spreading of ancient and mediaeval Indian history and culture (literature, religion, philosophy). This is due to the fact that the great part of the Tibetan works translated into English by Csoma are of Indian origin, only their original sources in Sanskrit or Pali had been lost or partially lost for posterity. Besides the undeniable and unique scientific achievements on the international level in his own time, we must not forget how much his work and his results contributed to later Hungarian-Indian relations. Quoting the words of Tibetologist and Csoma researcher Géza Bethlenfalvy: 'It can undoubtedly be said that Sándor Kőrösi Csoma is not only the founding father of Tibetan Studies but also of Buddhism research' (Bethlenfalvy n.d.: 8).

For his scientific merits, the Hungarian Learned Society elected him as a corresponding member in 1833, and he was conferred the title of Honorary Member of the Asiatic Society of Bengal in 1834. As a recognition of his results in studying Buddhism, he was declared a bodhisattva in 1933 by the Taisho University in Tokyo, and a Csoma statue created by sculptor Géza Csorna was placed in the aula of the university (Hetenyi 1972, Chandra 1992). ${ }^{12}$

Finally, we must not neglect mentioning the name of a painter of Hungarian origin, Ágoston Schöfft (1809-1888). His name became known by the Hungarian public as the author of the only authentic portrait of Sándor Körösi Csoma. However, it is much less a common knowledge that during his years spent in India between 1838 and 1842, he had a significant contribution to the artistic portrayal of the historical personalities and events of his age. He produced several paintings, for instance, of the ruler of Lahore, Maharaja Ranjit Singh, as well as his family and entourage. Most of his paintings created in India are exhibited in the Lahore Fort Museum in Pakistan, ${ }^{13}$ but there are quite a few copies displayed in Great Britain, in the National Sikh Heritage Centre \& Holocaust Museum functioning in Derby.

11 The two great collections of sacred Buddhist texts.

12 While there is no doubt about the existence of the Csoma statue, there is a dispute in the specialist literature about Csoma's life regarding his initiation as a bodhisattva (Hetenyi 1972, Kelényi 2012).

13 The large painting ( $487 \times 254 \mathrm{~cm}$ ) depicting the maharaja and his household can be found here, for instance, just like another of his famous works, showing Ranjit Singh and his suite at the Golden Temple of Amritsar (193.5 x $104 \mathrm{~cm}$ ). 


\section{From the Death of Körösi to Tagore's Visit to Hungary (1842-1926)}

The most important characteristic of this period was that a series of Hungarian translations of Indian religious and literary works were published. Without aiming to come up with a full list, it is certainly worth mentioning the Mahābhārata, appearing in the translation of Károly Fiók (1857-1915) in 1885, the partial translation of the Rāmāyana in 1903, the translation of Śakuntalā, the drama of Kālidāsa (1887), the translation of Hitopadeśa signed by Sámuel Brassai (1797[1800?]-1897) in 1884, or the other work of Kālidāsa, the $1^{\text {st }}$ canto of the Kumārasambhavam in the translation of Manó Michálek (1838-1894).

The first Hungarian translation of the Law Code of Manu also came out in 1914, published by the Law and Social Science Department of the Transylvanian Museum Society, linked to the name of Pál Büchler (1877-1946). ${ }^{14}$ This is the period when the most significant József Schmidt (1868-1933) translations and independent works were born, too. It could be enough to mention the first complete translation of the Pañcatantra (1924), yet he also published the translations of quite a few Indian plays. Among his own works, one must mention the monographs of literary history entitled Az ó-ind epika [Ancient Indian Epic Poetry] (1921) and A szanszkrit irodalom története [The History of Sanskrit Literature] (1923) as well as the monographs of religion and history of philosophy entitled Buddha élete, tana és egyháza [The Life, Teachings, and Church of Buddha] (1920) and Az ind filozófia [Indian Philosophy] (1923). This is the period when Tivadar Duka (1825-1908) is writing his works. He is forced to leave Hungary after the surrender of the 1848-49 revolutionary forces at Világos and decides to serve as a medical doctor in India, under British authority. Arriving in the distant country, he works in the beginning as medical officer in the English army in Bengal and then serves as a regional physician. During his stay in Calcutta, he gets into contact with one of the clerks of the Asiatic Society in Bengal, who urges him to start exploring Sándor Kőrösi Csoma's life and work in India. Tivadar Duka is the author of the first Kőrösi monograph, appearing in 1885 in English and Hungarian. ${ }^{15}$ At the same time, he also played an important role in the evolution of Aurél Stein's (1862-1943) career as this young Hungarian researcher interested in the East was able to travel to India in 1887 with the help of Tivadar Duka. Although Stein became world-famous due to the archaeological excavations in Inner Asia, ${ }^{16}$ he also had an important contribution, both directly

14 Büchler, Pál. 1915. Manu törvényei [The Laws of Manu]. Budapest: Erdélyi Múzeum Egyesület.

15 The English language publication appears in London under the title of Life and Work of Alexander Csoma de Körös. The title of the Hungarian monograph is Körösi Csoma Sándor dolgozatai [The Papers of Sándor Csoma Kőrösi], and it was published in Budapest.

16 During the three archaeological expeditions organized in 1900-1901, 1906-1909, and 19131916, he makes discoveries of invaluable importance, resulting in extremely significant objective 
and indirectly, to the enrichment of Hungarian-Indian relations. Above all, it must be emphasized that the translation of the $12^{\text {th }}$-century Sanskrit-language Rājataramgin̄ī, in fact the only authentic source about the mediaeval history of the Western Indian region, including Kashmir, is connected to his name. His scientific merits were recognized by both the British and the Hungarian scientific life. The declaration about Stein of Denisson Ross, the Orientalist, commissioned to make a catalogue of the Stein collection of the British Museum, is quoted in one of the essays of Géza Bethlenfalvy: 'rarely has a single person incorporated so many endowments for discovery, [...] a scholar, historian, geographer, and athlete in one person. Two nations can be proud of this great Hungarian, and he deserves the admiration of all' (Bethlenfalvy 1987: 60). The translations appearing in these years differ from the ones of the previous period in the sense that their greater majority are translated into Hungarian directly from the original language, excluding any intermediary languages, which, on the one hand, makes them significantly more valuable and, on the other hand, they make the masterpieces of Indian culture, of Sanskrit literature available to a much larger circle. Independent monographs based on research are important because by their means Indian religions, philosophy, and Indian culture are brought closer to the Hungarian readers, to those interested in Eastern cultures.

The most important event of the period is linked to the year 1873, when the Indo-European Language Institute is established at Pázmány Péter University. This institute functioned until 1920. It is considered a milestone in HungarianIndian relations from the perspective of our topic because from that moment on the teaching of Sanskrit is institutionalized. Although it would be worthwhile writing more in detail about the importance of this historical moment, we have to content ourselves with mentioning that during its existence the institute was supervised by such excellent scholars like Aurél Mayr (1846-1915) or József Schmidt (18681933). Following 1920, the teaching of Sanskrit was not discontinued, it only lost some of its weight as it was not done within an institutional framework anymore. Reorganization in a formal framework is connected to the name of János Harmatta, under whose supervision an Indo-European Language Department was established at Eötvös Loránd University, where the teaching of the Sanskrit language and of Sanskritology started again in 1956 and where Indology was later

finds. Perhaps his greatest discovery are the immense collections of very old manuscripts and paintings (manuscripts written in Sanskrit, Chinese, Tibetan, and other Asian languages, small objects of piety, Buddhist paintings and statues, etc.) found in a walled-up cell of the Caves of the Thousand Buddhas located in Dunhuang, on present-day Chinese territory, at the edge of the Gobi Desert. The uncovered treasures enrich the collections of museums in London and Delhi, and his remaining works are considered useful readings even today. A key role in the Dunhuang discovery was played by geographer Lajos Lóczy, who had already visited the cave temples with the expedition of Béla Széchenyi (Miklós 1999). 
also introduced. Over the decades, the best Indologists of Hungary came from this programme ${ }^{17}$ (Töttössy 1987, Négyesi 1987).

One must mention here that in 1919 the Ferenc Hopp Museum of Asiatic Arts was established, which would quite soon become the museum with one of the greatest Indian collections in Hungary. The person the museum was named after, trader, photographer, and art collector Ferenc Hopp, who in fact made the foundation of the museum possible by the works of art that he had bought during his five journeys around the world, played an outstanding role in its establishment. In his will, he left his collection as well as his villa located at 103 Andrássy Street to the Hungarian State with the aim of transforming it into today's museum. Tivadar Duka (1825-1908), whose own collection left for the Hungarian National Museum was transferred to the newly established museum, played an important role in enlarging the collection. The Indian collection was made significantly bigger by the contribution of the Indian art-dealer of Hungarian origin Imre Schwaiger (1864-1940), who, preparing to liquidate his shops in the British capital upon his retirement, donated four large cases of materials to the museum. The former director of the museum, Transylvanian-born art historian Zoltán Felvinczi Takáts (1880-1960) played a key role in the enlargement of the Indian collection of the museum (Fehér 1987).

One of the most outstanding moments of all-time Hungarian-Indian relations is connected to Rabindranath Tagore's visit to Hungary. The writer, poet, philosopher, composer, and the 1913 winner of the Nobel Prize had already enjoyed a great interest in Hungary even prior to his arrival at Budapest. Even if the great poet of Bengal had been almost completely unknown for the public in Hungary before obtaining the highest prize in literature, this state of affairs changed radically in a short time. The first Tagore translations appeared as early as $1913,{ }^{18}$ and subsequently many works of Tagore appeared in Hungarian translated by Ferenc Kelen, Mihály Babits, Lajos Áprily, Margit Kopácsy, etc. (Bangha 2011). In fact, before his visit to Hungary in 1926, the following of his volumes of verses could already be read in Hungarian: Lover's Gift (1921), Stray Birds (1921), Gitanjali - Song Offerings (1922), The Crescent Moon (1922), Crossing (1922), and Harvest [Fruit-Gathering] (1923). Similarly, three of his dramas had already been translated: Chitra (1920), Sacrifice (1920), and The Post Office (1922). Of his novels, three had been translated, namely Bimala (1921), The Wreck (1922), and Gora (of which only the 1973 reprint edition remained). From his volumes of short stories, Mashi (1920), Once There Was a King (1920), Auspicious Moment (1921), Homecoming (1921), and Hungry Stones (1922) appeared in full or

17 The names of Géza Bethlenfalvy (1936), Ildikó Puskás (1942-2009), Gyula Wojtilla (1945), György Karsai (1953), Mária Négyesi (1953), Ferenc Ruzsa (1957), and Zsuzsanna Renner (1959) must be mentioned here. Mihály Babits was among the first translators, with parts of the Gitanjali published in Nyugat. 
partial translation. In addition to these, three of his significant essays had been published, The Recognition of Life: Sādhanā (1921), The Inspiration of the Soul (1922), and Nationalism (1922), just like his memoir, entitled My Reminiscences (1922) (Wojtilla 1987, Bangha 2011).

Apart from the mentioned works, Ervin Baktay published a short, 48-page biography of Tagore in 1921 (Rabindranath Tagore). In 1922, he extended it to 272 pages and published it again under the title Rabindranath Tagore: The Man, the Artist and the Sage.

In the light of the above, it can be concluded that at the time of his visit to Hungary in 1926, Tagore was seen as a well-known albeit divisive personality by Hungarian intellectuals. Arriving at the Keleti Railway Station of Budapest, the Indian poet is greeted by a large gathering of people. His lecture entitled Civilisation and Development held on 26 October at the Music Academy generates a similar interest. Several records of the event remained: among others, the lines of Dezső Kosztolányi published in the columns of Nyugat [West], in which he writes about the impressions that the poem told by the poet had on him. In fact, the Hungarian poet was not very impressed by the lecture but was rather charmed by the poems told in Bengalese by Tagore after his lecture. Kosztolányi wrote the following:

[...] I am paying attention, mouth agape. Rabindranath Tagore recites one of his poems in his mother tongue. I have been told that this spectacle of his fascinated listeners in every corner of the world, and from the outset I felt contempt for those enjoying such presumptuous mumbo jumbo. Still, here I join them already. [...] I have already written that we come to like poems first and only then do we understand them, through our liking. I already like this one, too, I just do not get its meaning yet. But I realize a presentiment, which is more than knowledge: what great man this person can be, what a great poet. (Kosztolányi 1926)

A similar opinion is expressed about Tagore by László Ravasz, the Bishop of the Danubian District of the Hungarian Reformed Church, a man of Transylvanian origin, who writes a short note about the poet in Református Szemle [The Reformed Review], talking with enthusiasm about Tagore, the poet, but declaring disappointment regarding the lecture he delivered on cultural history, which was far from his expectations:

Rabindranath is one of the greatest poets of the world. As a man coming from the East, he is able to feel moods, see images, and express such refined vibrations of life that are outside the experience of Western people. [...] Visiting Budapest, he delivered a lecture on cultural history. It seems 
amazing how little he understands these issues. He moves helplessly in the world of notions, assigns other meanings to universal things than Western science would yet without being able to convince us to accept these new meanings. [...] Generally speaking, notions, definitions, systematization, inductive and deductive thinking, formulating theses, and conclusions are not his craft. He understands these like a nightingale would understand musical theory. (Ravasz 1926: 621)

There are material reminiscences of Tagore's visit to Hungary. The poet was treated with heart troubles at the sanatorium of Balatonfüred, and to express his gratitude in an Indian way he planted a tree on the shore of Lake Balaton. The tree can still be seen on the promenade later named after him, which also features a bust of Tagore since 9 October 1956. On the occasion of the tree planting, the poet wrote a poem in English:

When I am no longer on this earth, my tree

Let the ever-renewed leaves of thy spring,

Murmur to the wayfarer:

The poet did love while he lived

The poet always remembered his treatment in Hungary and the hospital in Balatonfüred with love and appreciation (Baktay 1941: 113-114).

Finally, I would like to underline as an interesting feature of the age that several members of the Hungarian aristocracy visited India during these years, spending there longer or shorter periods of time. Descendants of such famous families such as the Andrássy or the Széchenyi family got in direct contact with Indian culture. Within this range of thoughts, it must also be mentioned that Miklós Horthy, the later Governor of Hungary, visited India, too, as a young officer (Bangha 2011).

\section{From Tagore's Visit to Hungary to the Independence of India (1926-1947)}

Tagore's visit to Hungary had a significant impact on the Hungarian-Indian relations. The fact that the guest had felt quite comfortable during his stay in Hungary, ${ }^{19}$ significantly contributed to receiving later such famous Hungarian scholars and artists like the Indologist Ervin Baktay, the Orientalist Gyula Germanus, painters Erzsébet Sas-Brunner and her daughter, Erzsébet Brunner, or

19 Ferenc Balázs writes about this in the fragment of his book dedicated to his visit to Shantiniketan: 'I especially like Hungarians because they are simple, natural, and humane. In the whole of Europe, I felt most at home among them in Hungary’ (Balázs 1975: 240-241). 
Transylvanian Unitarian minister Ferenc Balázs at his university in Shantiniketan, one of the modern educational centres of his age, a meeting point and a place of synthesis of Western and Indian culture.

The line of visitors to Shantiniketan is opened by Ferenc Balázs (1901-1937), who, in his book documenting his journey around the world, writes in high regard of Tagore and his experience in Shantiniketan. The visitor felt a profound admiration for Tagore's rich personality, who could simultaneously be 'a poet, a philosopher, a composer, a pedagogue, a social reformer, a family man, a saint, a friend, a scientist and a believer' (Balázs 1975: 244).

A less positive reaction is expressed after his meeting with Tagore by Ervin Baktay (1890-1963), who arrives at Shantiniketan in the first days of 1929. The meeting with the poet was such a negative, disappointing experience for Baktay that he left Shantiniketan earlier than planned. The reason for his disappointment was the contradiction he felt between Tagore's artistic greatness and depth, something he had been aware of before, and the human nature manifesting itself through the behaviour and attitude of the person behind the works. He described the poet in his memoirs as reserved, withdrawn, and cold. The Hungarian Indologist also found that while Tagore praised self-denial, simplicity, and unpretentiousness in his literary works, the environment that surrounded him did not show that kind of attitude (Baktay 1941).

The passion of the Orientalist for India - as he himself confesses - originated in his childhood. He came across Indian culture for the first time in secondary school. After having read the Hungarian translation of the Śakuntalā, he remained with very strange, unexplainable observations and experiences. The world revealed by the work was simultaneously curious and mysterious yet also very familiar at the same time. He felt as if experiences from a previous life had come back to him (Bethlenfalvy 1990).

The years spent in India by Baktay and the knowledge and experience gathered by him during his stay there, resulting in articles, essays, and books, served as reliable first-hand information for those interested in Indian culture in Hungary. $\mathrm{He}$ is one of the most knowledgeable Orientalists of his age, with one of the richest list of publications. If we approach Baktay's intellectual legacy from the point of view of Hungarian-Indian cultural relations, his most important works are probably his book on Tagore, the two volumes published in 1931 entitled India, his books on Sándor Kőrösi Csoma, and his work of two volumes entitled Indiai éveim [My Years in India]. If we approach the author from the direction of his international reputation and notoriety, then it becomes evident that his monograph about Indian art history, the volume entitled India múvészete [The Art of India] appeared in 1958 brought him international fame. ${ }^{20}$ The originality

20 The book also appeared in German translation in 1963 with the title Die Kunst Indiens, which provided a lot more visibility to Baktay on the international scene. 
of his oeuvre can perhaps be grasped by the fact that he informs about every aspect of Indian life and culture in his writings, including the lives of simple people, religion, traditions, built heritage, or even the Indian landscape. His works provide an excellent alloy of scholarly quality and easy readability - hence their popularity.

The line of Hungarians arriving at Shantiniketan includes Gyula Germanus (1884-1979), who, accepting Tagore's invitation, taught subjects related to Arabian literature and Islam for three years at the university operated by the poet. His wife, Rózsa G. Hajnóczy accompanied him on his journey. She later shared her Indian memories and experiences with the Hungarian readers in a novel entitled Bengáli tüz: Három év története [Bengal Fire: The Story of Three Years]. After returning home, Gyula Germanus formulates very critical remarks about his years in India, the experiences he gathered there, expressing a devastating opinion about Tagore himself and also about Gandhi. The two outstanding personalities of Indian history are described as hypocrites and tyrants. Similarly to Baktay, he blames Tagore for singing of simplicity in his works but not being like that personally, rather living his everyday life in much more luxurious circumstances. What is more, he does not only expect simplicity and self-denial from his employees at the colony of Shantiniketan but even rules over them. Germanus considers Gandhi a self-seeking, cunning person, who uses the passivity of Indian people for the sake of his own purposes (Bangha 2011). At the same time, he condemns the romantic attitude towards India so fashionable in his time in European intellectual circles, and he takes an unambiguous stance with regard to the aims of the fight for independence hallmarked by the name of Gandhi. He writes about that in an issue of Budapesti Szemle [Budapest Review] in 1933 like this:

India can only secure its future within the political framework of the British Empire, as its integral part, with the dissemination of European civilization in the widest possible layers of its society. Let us not idealize the past and judge one-sidedly based on gorgeous temple ruins and tombs. Europe, with its despised materialism and machines, has done much more to liberate the human spirit than abstract Indian philosophy, which had allowed 100 million souls the fate of coolies. Let us not idealize the past through the lens of the present and only see the high-flying thoughts of a few prominent thinkers, but let us observe tyranny, the famine after a missing monsoon, the contagious diseases and the even more contagious superstitions. English rule has brought about the material culture that created democracy, newspapers, railroads, courts of justice, medicine, and 'last but not least' the dearest endeavour of present-day India: nationalities and equality in rights. (Germanus 1933: 299) 
Later on, he significantly changes his opinion about his Indian years, and in the 1960s he speaks about Tagore and Shantiniketan on several occasions in positive terms of recognition. Below I quote two such passages:

The poet, called 'Gurudev' (divine teacher) by his co-workers, created a monumental scientific synthesis of European and Indian teachers and artists, aiming to present the world the specific role of India: the cooperation for the benefit of all people, of all races and nations through common work. Along with English, American, Dutch, Russian, French, Czech, German, Italian teachers, Japanese, Chinese, Tibetan and, of course, a large number of Indian researchers and teachers could visit each other's lectures and could mutually support each other in their scientific work. (Germanus 1956: 7)

In Shantiniketan, there was no constraint for learning. Youth was drawn there from all parts of India by the pursuit of knowledge, with eighty female students among them, which was a daring innovation at that time in India. After the death of Tagore, Shantiniketan became a public university. (Germanus 1956: 7)

There are several theories trying to explain this radical change in the discourse of Germanus. Without entering into many details, the explanation that connects this change to the cultural spirituality of the age seems to be the most acceptable one, emphasizing that in the 30 s and the 40 s the judgment and popularity of Tagore declined significantly, while after the liberation of India and the 1956 Hungarian revolution it increased again, Hungarian readers celebrating in him the greatest poet of the free and friendly India, the bard of freedom (Bangha 2011).

And if we are talking about Tagore University in Shantiniketan we cannot forget to mention the two Hungarian painters, Elizabeth (Erzsébet) Sass-Brunner (1889-1950) and her daughter, Elizabeth (Erzsébet) Brunner (1910-2001), who arrived in India in 1930, answering a mystical call, a strange dream; ${ }^{21}$ after a short stay in Bombay, they travelled on to Calcutta, where they met Tagore. Following that, they spent long years at the university of Shantiniketan, with shorter and

21 Following World War I, Erzsébet Sass-Brunner gets into an existential crisis, and this is the moment when she comes in contact with Indian culture through the work and personality of Tagore. In the spring of 1929, she decides to leave Hungary and travel to India. She takes her daughter with her, who, during their stay in Southern Italy, sees a strange, mystical dream in which an old man with white hair and beard appears in front of her with a candlelight in his hand, asking her to take that light to every corner of the world. The mother believes to recognize Tagore in the dream, and as a consequence of the dream she sends a letter to the poet in Hungarian, writing only 'Rabindranath Tagore, India' on the envelope. Two months later, she does receive an answer, in which the poet invites the paintress and her daughter to Shantiniketan. 
longer breaks, before settling down in India definitively. ${ }^{22}$ While the painting of Erzsébet Sass-Brunner is more characterized by mystical themes, Himalayan landscapes, and Hindu god representations, among the works of the younger Erzsébet, portraits represent the most outstanding value. The artistic bequest left behind contains numerous portraits of famous Indian personalities of the time, but many depict holy Indian persons or just simple peasants. She was among the first ones to paint the portraits of the Dalai Lama, Rabindranath Tagore, Gandhi, Jawaharlal Nehru, Sarojini Naidu, Vinoba Bhave, the child Rajiv Gandhi and his brother, Sanjay Gandhi, and of several other historical personalities. The artistic value of her paintings can be best reproduced by the words of Tagore and Gandhi, who said the following about them:

Mrs and Miss Brunner have in my opinion artistic gifts of a high order. I am sure their sensitive brushes have caught the life and colour of our landscape and the spirit of the human nature in India. (Bethlenfalvy 1979)

I was much pleased to meet Mrs Sass Brunner and her daughter Elizabeth. They were good enough to show me some specimens of their paintings of rustic life. Though I am no judge of painting, I could not fail to notice a faithful reproduction of typical villagers. What, however, touched me most was their love for India and her masses. (Bethlenfalvy 1979)

The artistic performance of the younger Elizabeth was recognized and honoured by both the Indian and the Hungarian State. In 1985, the Government of India conferred the paintress one of the highest awards for artistic performance, the Padma Shri Award. ${ }^{23}$ In Hungary, she was rewarded for the first time in 1988, receiving the Order of the Flag of the People's Republic of Hungary (Magyar Népköztársaság Zászlórendje), while after the 1995 change of the political system she was also conferred the Hungarian Cross of Merit ( $A$ Magyar Köztársaság Középkeresztje). She received two further distinctions: the university in Shantiniketan made her an honorary doctor in 1997, and her native town of Nagykanizsa conferred her the title of honorary citizen. A great part of her works is brought back to Hungary following her death; part of them are in the collection of the museum of Nagykanizsa, while another part enrich the painting collection of the Ferenc Hopp Museum of Asiatic Art.

22 Between 1935 and 1938, they visited Japan, the USA, England, and Hungary. In 1938, they were invited by the Maharaja of Baroda to work for him, so they decided to return to India. Subsequently, both of them lived their entire lives in India and have their graves in Naini-Tal, Northern India.

23 The Padma-Shri Award conferred by the Indian State is the fourth highest civilian award in the Republic of India: it corresponds to the Kossuth Prize in Hungary. 
Another symbolic, iconic figure of the cultural relations of the two countries is the Hungarian-Indian painter, Amrita Sher-Gil (1913-1941), who, although disappearing very young at the age of 28 , is considered to be one of the most influential, pioneer representatives of modern Indian painting. The artist, born as the daughter of a Sikh aristocrat father and a Jewish Hungarian mother, saw the light of the day in Budapest and spent most of her childhood in Hungary. After a short stay in India, the family moved to Paris in order for the talented Amrita to study painting at one of the best art universities of her age, the École Nationale Des Beaux Arts. ${ }^{24}$ The last years of her life find her in India again, painting the most important and valuable pieces of her artistic career. Her works, although they predominantly react upon Indian reality and traditions, also bear easily recognizable European influences. The fame and success of the artist often called the Indian Frida Kahlo was far greater in India than in Hungary, where nevertheless several biographies, essays, and catalogues have lately been published about her, ${ }^{25}$ and a few exhibitions were also organized. ${ }^{26}$ The monumental oeuvre that the Hungarian public just recently started to learn about is considered to be a national treasure in India. Her works, rarely found at auctions, are quite sought. At the 2015 March auction of Sotheby's in New York, her self-portrait from 1933 was sold for 2.92 million dollars, making it the most expensive painting ever made by an Indian paintress.

\section{From the Independence of India to the Change of the Political System in Hungary (1947-1989)}

Indian independence, achieved on 15 August 1947, opened up a new period in the history of Hungarian-Indian cultural relations. Hungary established diplomatic relations with India as early as 1948, which was raised to an ambassadorial level three years later. After an initial short and unfriendly period, ${ }^{27}$ the relationship between the two countries became settled and then pronouncedly good.

24 Her father, Umrao Singh Sher-Gil (1870-1954), was the descendant of a rich aristocratic family in Punjab, while her mother, Marie-Antoinette Gottesmann (1881-1949), was the sister of Ervin Baktay.

25 Rónay, Eszter: Amrita Sher-Gil. Kiállítás katalógus [The Catalogue of the Exhibition] (2001); Keserú, Katalin: Amrita Sher Gil (2007); Alfredo de Braganza: Amrita. Egy magyar nő, aki India legnagyobb festômúvésze lett [Amrita, a Hungarian Woman, who Became the Greatest Painter of India] (2016).

26 Exhibitions to commemorate Amrita Sher-Gil were opened in Budapest in the years 2001 and 2013 and in Zebegény in 2015.

27 During the Rákosi era (1947-1956), India in fact did not belong among the friendly countries. The Hungarian political élite saw Gandhi as an enemy of the people, who, with his religious fanatism, made the awakening of the Indian people impossible, and in Nehru they saw the representative of Indian bourgeoisie, who did not stand on the side of the simple people but served the imperialists. 
Especially as a result of the mutual visits of Soviet and Indian leaders to each other's country, ${ }^{28}$ during which both parties expressed unambiguous commitment for co-operation, India became an important friend also for Hungary.

The best examples for the friendly relationship of the two countries are the mutual, high-level state visits. During the period discussed, i.e. over the four decades in question, two Hungarian presidential and three prime ministerial visits $^{29}$ took place, while from the Indian side three heads of state and two prime ministers ${ }^{30}$ visited Hungary. During these high-level visits, the two parties signed numerous agreements. From the point of view of our topic, the most important one of these was the Indo-Hungarian Exchange Programme concluded in 1962, which made possible for the students, researchers, and artists of the two countries to pursue studies in the other country. This programme of mobility significantly contributed to the establishment of living cultural relations as well as permitted the participants to extend their knowledge during shorter or longer study programmes and further education opportunities. It had an important role in the growth and accomplishment of the new generation of Hungarian Orientalists, Indologists, and linguists as many of them could go to study at Indian universities and research institutes within the framework of the programme. Many of the graduates of the Indo-European Language Institute relaunched in 1952 within Eötvös Loránd University carried out outstanding scientific activities. The names of Géza Bethlenfalvy, Ildikó Puskás, Mária Négyesi, Vera Gáthy, Gyula Wojtilla, Ferenc Ruzsa, and Zsuzsa Renner can be mentioned here, and the list could continue.

It was also a nice expression of the friendly relationship between the two countries that a bust of Tagore donated by the Indian State to Hungary was unveiled in the presence of A. K. Chandra, the Indian Deputy Foreign Minister, and Krishna Menon, the Indian Ambassador to Hungary, in 1956 in Balatonfüred, in the immediate vicinity of the tree that Tagore himself had planted during his visit to Hungary. High-ranking officials of the Hungarian State participated in the festivity along with quite a few representatives of the Hungarian professionals in the field. Ervin Baktay, Lajos Ligeti, István Rusznyák, the President of the Hungarian Academy of Sciences, and Pál Ignotus, member of the Presidium of the Hungarian Writers' Association were present there. Gyula Germanus wrote an article about the event in the 9 October issue of Magyar Nemzet [Hungarian Nation], entitled Emlékezés Rabindranath Tagoréra [Remembering

28 In May 1955, Nehru is the first to arrive to an official visit in the Soviet Union, and after that, in December, Khrushchev was received in Delhi.

29 Of the Hungarian heads of state, Pál Losonczi (1969 and 1976) and of the prime ministers Ferenc Münnich (1962), Gyula Kállai (1966), and Jenő Fock (1974) paid official visits to India.

30 From the Indian side, presidents Zakir Hussain (1958), V. V. Giri (1970), and Fakhruddin Ali Ahmed (1976) and prime ministers Indira Gandhi (1972) and Rajiv Gandhi (1988) came for official visits to Hungary. 
Rabindranath Tagore]. All the important papers of the period related about the unveiling of the statue. ${ }^{31}$

Among the inaugural speeches, the Deputy Foreign Minister of India spoke in beautiful terms of the Indian-Hungarian relations, noting that: 'For me, as for someone who had been the secretary of Tagore for many years, it is a special joy to see that his visit to Hungary is still remembered with respect. The offering of this statue is some sort of a late expression of the gratitude that my people feel for the people of Hungary, for taking good care of, and healing Tagore.'

Naturally, a significant amount of Indian literature translated into Hungarian appeared in this period, too, which made available Indian religious literature and Indian fiction to Hungarian readers. The new generation of Orientalists play an important role in this translation task. However, original works, books written with scientific rigour or aimed at the general public are even more important in this period. The first Gandhi monographs connected to Vera Gáthy ${ }^{32}$ and György Kalmár ${ }^{33}$ must be mentioned in this context. The book written by Ildikó Puskás and published by Gondolat Kiadó in 1984 under the title Istenek tánca. Rövid áttekintés az indiai vallásokról [The Dance of Gods. A Brief Overview of Indian Religions] also belongs to the same category. And the list could be continued with the books on yoga written by Béla Vigh ${ }^{34}$ or the volume of Olivér Téchy on Buddha and Buddhism..$^{35}$ But this is the period when the highly successful volume presenting Indian art history and signed by Ervin Baktay also appeared..$^{36}$

Among the literary creations connected to Indian culture, we must mention the play written by László Németh in 1957, by which the author wished to commemorate Mahatma Gandhi. His work entitled Gandhi halála [The Death of Gandhi] is nothing else in fact but a particular interpretation of the principles and laws according to which the Great Soul lived his entire life. Although the final tone of the drama is a pessimistic one, suggesting that the Gandhian way of life, teaching of peace, non-violence, and love, is in fact hopeless because

31 Szabad Nép [Free People] XIV(280) - Szobrot emelünk Rabindranath Tagorénak Balatonfüreden [A Statue is Erected to Honour Rabindranath Tagore in Balatonfüred]; Szabad Nép XIV(282) India külügyminiszterhelyettese avatta fel Tagore szobrát Balatonfüreden [The Deputy Foreign Minister Unveiled Tagore's Statue in Balatonfüred]; Magyar Nemzet [Hungarian Nation] XII(238) - Emlékezés Rabindranath Tagorére [Remembering Rabindranath Tagore]; Magyar Nemzet XII(239) - Leleplezték Rabindranath Tagore szobrát Balatonfüreden [Rabindranath Tagore's Statue Was Unveiled in Balatonfüred]; Népszava [The Voice of the People] 84(239) - Felavatták Rabindranath Tagore szobrát [Rabindranath Tagore's Statue Was Inaugurated].

32 Gáthy, Vera. 1970. Gandhi. Budapest: Akadémiai Kiadó.

33 Kalmár, György. 1982. Mahátmá Gandhi. Álom - politika - valóság [Mahatma Gandhi. Dream Politics - Reality]. Budapest: Gondolat.

34 Vigh, Béla. 1972. Jóga és tudomány [Yoga and Science]. Budapest: Gondolat-Vigh, Béla. 1980. A jóga és az idegrendszer [Yoga and the Nervous System]. Budapest: Gondolat.

35 Téchy, Olivér. 1986. Buddha. Budapest: Gondolat.

36 Baktay, Ervin. 1958. India múvészete [The Art of India]. Budapest: Képzőmúvészeti Alap Kiadóvállalata. 
aggression, hatred destroys it, still, it sets this way of life in front of us as a value to follow both in a political and a moral sense. The work gained its final form in 1962 and is presented as a theatrical performance in 1973 in Thália Theatre. Preparing for the $150^{\text {th }}$ anniversary of Gandhi's birth, the work also appeared translated into Hindi in 2018 as a joint effort of poet-translator Girdhar Rathi and university professor, linguist, and translator Margit Köves. ${ }^{37}$

The Hungarian Information and Cultural Centre in Delhi, established by the Hungarian State in 1978 (today part of the Balassi Institute's network) - which until recently has been the only such institute of Hungary on the Asian continent $-{ }^{38}$ continues to play a very important role in creating a bridge between the two cultures. Browsing the webpage of the institute and its profile in social media, we can get a comprehensive picture of its activity, which is truly rich and varied, serving its cause of spreading Hungarian culture and language in India with substantial events and performances. We find exhibitions, musical evenings, readings of poets and writers, film projections, Hungarian language classes for Indians, and book publications among the 120-130 events organized annually. Regarding the aims and the mission of the institute, one can read the following on their webpage:

The most important target of our institute is to strengthen the cultural, scientific and educational relations between the two countries as well as to increase the existing ones. Our Centre is also responsible for certain tasks of cultural diplomacy. We assist Hungarian scholars and scientists in finding the right Indian partner institutions, and pay attention to scholars so that they can utilize their scholarships in the most efficient manner while being in India. Our Centre's networking system facilitates research scientists and universities from Hungary and India to be able to contact each other, and also, that Hungarian and Indian ensembles can give guest performances in each other's countries. A good number of Indian students can study in Hungarian universities with the help of the Hungarian Centre. Hungarian language class students can learn Hungarian also in the Hungarian Centre and some of them have become recognized translators by now. (website of the Balassi Institute HICC)

The Hungarian-Indian Friendship Society played an enormous role in making Indian culture and religion known in Hungary. The organization founded in 1929 is connected to the name of artist and writer Ferenc Zajti (1886-1961), a teacher interested in Orientalism, who had in fact also invited Tagore to Hungary. However, the society did not have a long life as World War II ended its functioning. After that, there had been several attempts to re-establish it, but the

37 Németh, László. 2018. Gandhi Ki Mrityu. New Delhi: Rajkamal Prakashan.

38 The Hungarian State opened the Hungarian Cultural Institute in Beijing in 2013. 
political leadership coming to power did not allow it to happen. Finally, its reestablishment occurred in 1988, and the Society has been functioning ever since. According to its statutes, the aim of the Society is to foster and continuously develop Hungarian-Indian cultural, economic, and social relations. For that sake, the Society organizes regular lectures, film projections, educational activities, exhibitions, and other types of events in Hungary.

Finally, when dealing with the period between 1947 and 1989, we cannot avoid briefly discussing the Hungarian revolution of 1956 and its Indian connections. And in this case India does not come into the picture as Western countries usually do, serving as a new homeland for the Hungarians fleeing from the country after the revolution had been defeated, but in the sense that after the defeat of the revolution the Indian political élite actively participated in the diplomatic lobbying activities aiming to minimize the retaliatory actions oriented against the revolutionaries. Three key figures play an enormous role in this process. One of them is a young Indian diplomat, Muhamad Attaur Rahman, who arrives in Budapest on 29 September 1956, and as a chargé d'affaires he has the task to create the conditions for the establishment of an embassy in Budapest. The other actor is the Indian ambassador in Moscow, who had been accredited to Budapest until the embassy in Hungary is established. Kumara Padmanabha Sivasankara Menon $^{39}$ (1898-1982) arrives in Budapest in that capacity on 2 December 1956 with the aim of obtaining information about the situation on the ground in Hungary. On the Hungarian side, the key actors of the story are Árpád Göncz ${ }^{40}$ (1922-2015), István Bibó ${ }^{41}$ (1911-1979), and Ervin Baktay. Bibó and Göncz are in permanent contact with chargé d'affaires Rahman, who in fact served as a connection between the political élite supporting the revolution and the Prime Minister of India, Jawaharlal Nehru: he delivered letters written by the regimechanging élite, prepared reports on the Hungarian situation, and - according to certain notes - he was the one to assist Ervin Baktay in travelling to India on 22 November 1956. Baktay meets Nehru personally and informs the Prime Minister about the situation in Hungary. The direct information received from Hungary significantly contributed to Nehru obtaining a clear view of the real happenings in Hungary, while the reports received from the Ambassador in Moscow, K. P. S. Menon, described the events as a counter-revolution. Nehru, without publicly condemning Soviet military intervention, relying on lobbying activities and the diplomatic work carried out in UNO with Khrushchev and Kádár, most probably contributed to the fact that in the trials of Bibó and Göncz the definitive judgment was life sentence and not capital punishment (Sándor 2008, Vida 1994, 1998).

39 Indian diplomat, ambassador.

40 Literary translator, writer, politician, and the first President of Hungary after the change of the political system (between 1990 and 2000).

41 Lawyer, political thinker, university professor, Minister of State in the government of Imre Nagy. 


\section{After the Hungarian Change of the Political System to the Present Days (1989-)}

Given the fact that this period is the closest in time to the present days, it is perhaps the most difficult to evaluate what happened in the past 30 years. It is a difficult undertaking because we lack the historical perspective necessary to talk about values and the creation of values on the one hand, and it is difficult because we ourselves are living in the period under study on the other hand; moreover, we are sometimes able to shape the processes, events. Still, we cannot avoid talking about this period, either.

First of all, it is perhaps important to underline that the cultural values and achievements of the period after 1989 are no longer impregnated by the socialist, communist ideology and its framework of interpretation forced upon almost everything by the former power. Thanks to this, it can probably be stated that the cultural products appearing after 1990, especially the ones linked to literature, finally appear without any kind of ideological restrictions, expectations, or constraints.

Albeit in the last decade the Hungarian-Indian economic relations have become particularly lively, the period after the change of the political system is also characterized by the fact that the two countries continue to be linked by an extremely strong cultural tie. This is what Gauri Shankar Gupta, former Indian Ambassador to Hungary, tells in an interview:

Indian-Hungarian relations can be qualified as extremely fruitful. They continue to strengthen, especially in the area of culture. This is marvellously shown by the new Indian cultural centre opened in the embassy building last November. It is one of the symbols of how well Indian-Hungarian relations are developing. In Delhi, a Hungarian cultural centre has been functioning since 1976. Both locations regularly organize cultural events, exhibitions, theatrical performances, all of which offer an extremely colourful programme for those interested in them. (Orsós 2011: 25)

And if the above interview fragment mentions the newly opened Indian cultural centre in Budapest, then perhaps it should be the first to briefly talk about. The centre was opened in 2010 and took the name of Amrita Sher-Gil in 2014, thus commemorating the paintress of Hungarian-Indian origin. The centre serves in fact similar purposes as its Hungarian counterpart, it is the pillar in Hungary of the Hungarian-Indian cultural relations. The events and programmes of the Amrita Sher-Gil Cultural Centre are very similar in nature to the programme offer of the Hungarian partner institution. In addition to the organization of lectures, film projections, exhibitions, various dance courses 
(dance, sitar, tabla, harmonium, yoga, etc.), and literary evenings, the centre also publishes a bimonthly magazine (Amrit), in which Hungarian, English, and Hindi language materials appear about Indian-Hungarian relations, culture, politics, or even economy. At the same time, the centre has got events organized in other towns, thus trying to take Indian culture closer to the Hungarians not living in Budapest. Since 2015, the centre has regularly organized the International Yoga Day event series, in which, besides yoga, the popularization of Indian culture, gastronomy, and artisanship also play an important part and which had introduced itself in 17 Hungarian cities by 2019. The GangesDanube Festival has been around since 2016, an event in which Indian dance groups, orchestras, and performers bring authentic Indian culture closer to the Hungarian public. In 2018 and 2019, the embassy and the cultural centre have organized numerous events to commemorate the $150^{\text {th }}$ anniversary of the birth of Mohandas Karamchand Gandhi. Of these, the conference organized in the Széll Kálmán Hall of the building of the Hungarian Parliament on 2 October 2018 must be mentioned, just as the commemorative stamp issued together with the Magyar Posta (the Hungarian Post) in early 2019. Finally, the Indian Film Festival is worth mentioning, too, which reached its sixth edition in 2019.

After the fall of communism, numerous high-level diplomatic visits took place both in Hungary and India. Not long after Árpád Göncz had been elected president, he embarked on an official visit to India. The special feature of the visit was that on this occasion Göncz and the former Indian chargé d'affaires, Rahman, met again, on which occasion Göncz conferred him the Order of the Flag of the Republic of Hungary Decorated with Laurels in recognition of his role played after the defeat of the revolution in $1956 .{ }^{42}$

Answering the invitation of the Hungarian head of state, the President of India, Shankar Dayal Sharma, pays a visit to Hungary in 1993. Bilateral relations were further strengthened by the visit in 2016 of Vice-President Hamid Ansari.

Meanwhile, three Hungarian prime ministers paid official visits to India, ${ }^{43}$ and numerous agreements, contracts were concluded. From the perspective of our topic, the most important agreements and contracts are of course the ones that positively influence one of the segments of the cultural sphere. We have to mention here primarily the co-operations in the area of education and research, of which I would like to highlight the agreement on scientific and

42 The decision about the award can be read on page 1766 of the 1991/82 issue of Magyar Közlöny [The Hungarian Journal]: 'Upon the submission of the Foreign Minister, in recognition of his outstanding activity for the development of Hungarian-Indian relations, I hereby confer the ORDER OF THE FLAG OF THE REPUBLIC OF HUNGARY DECORATED WITH LAURELS to retired Ambassador Mohammad A. Rahman. Undersigned by Árpád Göncz, the President of the Republic.'

43 Official visits to India were done by Péter Medgyessy (2003), Ferenc Gyurcsány (2008), and Viktor Orbán (2013). 
technological co-operation functioning since 1992 and which selects common research projects within two-year working plans. In 2008, this co-operation was extended by another agreement, which created a common research fund and which offers priority support for joint research and development projects in the area of green chemistry, biomedicine, electronics, optics, and space research. At the same time, the scientific academies of the two countries have also concluded a bilateral agreement.

Another important agreement in place since 2006 refers to cultural exchange programmes. In fact, it supplements and raises on a new level the agreement on cultural co-operation signed in 1962. Due to this exchange programme, several projects are implemented annually, making it possible for the general public interested in the other culture to get in direct contact with the culture of the other nation, the partner country.

The two countries signed an agreement about an educational exchange programme in 2014, which provided a framework for mutual scholarship mobility opportunities for the citizens of the two countries. Following the conclusion of the agreement, the Hungarian party offered 200 places annually within its Stipendium Hungaricum programme for students wishing to study in BA and MA programmes in Hungary, ${ }^{44}$ while the Indian party, in the spirit of mutuality, offered 35 post-graduate and $\mathrm{PhD}$ places for Hungarian citizens. ${ }^{45}$

Finally, I would like to call attention to another important phenomenon. Following the 1989 change of the political system, several new institutions, organizations, and associations linked to Indian religions and culture have appeared in Hungary. In this context, we must mention the Dharma Gate Buddhist College established in 1991. On the webpage of the higher education institution, in connection with its mission, we can read that their primary goal is to introduce the Buddhist tradition to Hungary. The founders are convinced that the basic principles of Buddhism are close to Hungarian and European spirituality; therefore, by their educational programmes, they would not only like to meet the needs of a narrow religious circle but wish to offer a new colour on the cultural palette in Hungary.

The first Indian Dance Theatre in Budapest was established in 1997, founded by Panni Somi. The dance group, known under the name Shiva Shakti Kalananda Dance Theatre, primarily wishes to introduce and endear the classical SouthIndian dance, the Bharatanatyam, to the audience in Hungary, but in addition to that it lays an important emphasis on the organization of programmes meant to popularize Indian culture and arts as well. During its 22 years of existence, the dance ensemble produced over 15 large-scale performances choreographed by

44 The opportunity is open for those interested in natural and life sciences, engineering, information science, and economics programmes.

45 Special areas: Hindi language, Indian culture, art history, and other areas of science. 
Panni Somi, which could be seen by the Hungarian audience on the stage of the National Dance Theatre.

In spite of the fact that yoga training has been available in Hungary since the 1930 s, ${ }^{46}$ it could only accomplish itself in the second half of the 1990s because the communist state machinery disapproved and sometimes even forbade the practice and teaching of the doctrines that were in contradiction with Marxist materialism, the official ideology of the era. Then, in the period after 1989, the various yoga schools started to proliferate. Today, there are over 280 qualified yoga trainers and around 20 qualified yoga schools active in Hungary, of which 7 are qualified training institutions. In order to control the process to some degree, yoga teachers and yoga schools created the Association of Yoga Trainers in 2006.

\section{Closing Remarks}

Before formulating any kind of conclusion, I wish to begin by saying that in the present paper, in the presentation and the analysis of the different periods, I did not aim at achieving completeness. I could not have done that without completely breaking the predefined formal boundaries of the paper. My objective was to flash a few events, processes, moments, personalities, or interconnections from the over 400-year old history of the Hungarian-Indian cultural relations, which deepened the good relationship between the two countries and took them forward. It may well be that some of my readers will consider that my selection was occasionally subjective, but let me invoke Ervin Baktay and paraphrase him, saying in my defence, that I tried to do everything to bring Hungarian-Indian cultural relations closer to the reader and allow it to be known by those interested. ${ }^{47}$

As a conclusion, it is worth underlining that, in spite of the immense physical, spatial distance between them, cultural connections and interferences between the two countries have evolved fairly early, which, as time passed, have grown

46 The first European yoga school was opened in Budapest by a young man of Indian origin, Selvarajan Yesudian (1916-1998), who had arrived to Hungary to pursue medical studies and who later on settled down there. In 1941, Yesudian's book entitled Jóga és sport [Yoga and Sports] appeared, which was such a tremendous success that it achieved nine editions in one and a half years. Growing motivated by the success, together with paintress Erzsébet Haich (1897-1994) they establish the first yoga school in Europe, which they continue to operate until 1948, when they are compelled to leave Hungary. In the preface of his book, he writes the following: 'Hungarians arriving from the East, in spite of Western civilization and materialism, succeeded to preserve within their souls the unspoilt spirit of ancient steppes, the spiritual sensitivity for the great secrets of nature, the wonderful sense for truth. Therefore, they are able to understand the ancient message of India, its health rules, and its thousand years old "sports" that I hereby present' (Selvarajan-Haick 1994: 9).

47 In his book entitled India, appeared in 1932, Baktay writes that: 'As far as it lied within my power, I tried to bring this land, India, closer and allow it to be known by those interested' (Baktay 1932: 320). 
deeper and more complex, turning into a relationship covering several cultural areas. This is due, among other things, to the fact that the connections between the two cultures have indeed always been defined by honest, open interest, based on mutual respect, irrespective of the historical periods. At the same time, it is also important to underline that the two countries have common values that are important for both, which are part of their national cultures, such as Amrita SherGil, the Brunners, or even Sándor Kőrösi Csoma.

If we wish to briefly summarize the characteristic features of the different periods and compare them with each other, then we must say that they are extremely different in what concerns their most relevant peculiarities.

The main characteristic of the first period is that the emphasis was on translated literature, which at the time appeared with the help of intermediary languages. This is changed by the work of Körösi, who lays the foundations of Tibetology, and by his translations from the Tibetan language he significantly contributes to studying the Hindu religion and culture.

Three important moments are worth mentioning from the second period. On the one hand, I consider it important that the teaching of Sanskrit is institutionalized in 1873, and, on the other hand, it has to be mentioned that the number of travellers to India driven by a conscious pursuit of knowledge and the desire to discover has significantly increased. Finally, Tagore's visit to Hungary must be mentioned here because in my interpretation it opened a new chapter of Hungarian-Indian cultural relations.

In the case of the third period, maybe it is not an exaggeration to say that although it only lasted a little bit longer than two decades, it brought extremely intensive connections and achievements. There are scholars and artists among the large number of visitors to India in this period. It was an extremely productive stage of the Hungarian-Indian cultural relations, both regarding translated literature and original works.

The fourth period brought about the opportunity of the institutionalization of Hungarian-Indian cultural relations. As a result of the achievement of Indian independence, existing and functioning relations could be raised on a diplomatic level. The two important moments of the period are the 1956 revolution and the role of India as well as the establishment of the Hungarian Information and Cultural Centre in Delhi.

Finally, in the case of the fifth period, it is worth emphasizing that through the accomplishment of the free and democratic Hungary cultural relations could become ideologically 'cleaner'. A very important moment in the cultural relations between the two countries is the creation of the Amrita Sher-Gil Cultural Centre. At the same time, it must also be mentioned that several cultural, educational, and research agreements have been concluded between the two countries in this period. 
As a closing remark, I would like to point out that on a cultural connection that is over four hundred years old and which had always been characterized by openness, honesty, and acceptance numerous new relations can be built easily in the future as a high level of trust had been formed between the two countries a long time ago. And although India is presently facing economic and domestic political problems, it is worth tuning in on this continent-sized country both in the short and the long term as it may well become an important and essential actor of world politics.

\section{References}

BAKTAY, Ervin. 1941. India. Budapest: Singer és Wolfner Irodalmi Intézet.

BALASSI INSTITUTE HUNGARIAN INFORMATION AND CULTURAL CENTRE, NEW-DELHI. Retrieved on: 15.07.2019, from: http://www.delhi.balassiintezet. hu/en/.

BALÁZS, Ferenc. 1975. Bejárom a kerek világot. Bucharest: Kriterion.

BANGHA, Imre. 2011. Jöttem a Gangesz partjairól. Bengáli kultúra és magyar irodalom. Budapest: L'Harmattan.

BETHLENFALVY, Géza. é.n. HUNDIA. Magánkiadás.

(ed.). 1979. A Vision of India. The Art of Elizabeth Sass Brunner and Elizabeth Brunner. Bombay-New Delhi-Calcutta-Madras-Bangalore: Allied Publishers Private Limited.

1980. India in Hungarian Learning and Literature. New Delhi: Munshiral Manoharlal Publishers.

1987. Magyar tudósok indiai munkássága. In: Bethlenfalvy, Géza-Puskás, Ildikó (eds), India magyar szemmel. Budapest: Indiai Nagykövetség. 58-61.

1990. Enchanted by India. Ervin Baktay (1890-1963). Life and Works. New Delhi: Hungarian Information and Cultural Centre.

1992. The Janus Face of Oriental Studies. In: Satinder Kumar, Vij-Lázár, Imre (eds), Alexander Csoma de Körös (1784-1842). Pioneer of Oriental Studies in Hungary. New Delhi: Department of Slavonic and Finno-Ugrian Studies, University of Delhi and Hungarian Information and Cultural Centre. 3-8.

CHANDRA, Lokesh. 1992. Alexander Csoma de Körös. In: Satinder Kumar, VijLázár, Imre (eds), Alexander Csoma de Körös (1784-1842). Pioneer of Oriental Studies in Hungary. New Delhi: Department of Slavonic and Finno-Ugrian Studies, University of Delhi and Hungarian Information and Cultural Centre. $35-42$.

FEHÉR, Judit. 1987. India múvészete a Hopp Ferenc Keletázsiai Múvészeti Múzeumban. In: Bethlenfalvy, Géza-Puskás, Ildikó (eds), India magyar szemmel. Budapest: Indiai Nagykövetség. 44-48. 
GÁTI, Vera. 1992. Indology in Hungary: Past and Present. In: Nyusztay László (eds), Hungarian Scholars on India and Indology. Lectures at HICC New Delhi (1989-91). Hungarian Information and Cultural Centre. 49-56.

GERMANUS, Gyula. 1933. A mai India. Budapesti Szemle 229(667): 274-299. Retrieved on: 10/07/2019, from: https://adtplus.arcanum.hu/hu/view/Budape stiSzemle_1933_229/?query=germanus\&pg=277\&layout=s.

1956. Emlékezés Rabindranath Tagore-ra. Magyar Nemzet 12(238): 7. Retrieved on: 10/07/2019, from: https://adtplus.arcanum.hu/hu/view/MagyarNemzet _1956_10/?query=India\%20saj\%C3\% A 1tos\% 20szerep\%C3\% A9t\% 20a\% 20 vil\%C3\%A1g\%20el\%C3\%A9\%20t\%C3\%A1rni\&pg=50\&layout=s.

HANCOCK, Ian. 2010. The Hungarian Student Vályi István and the Indian Connection of Romani. In: Dileep, Karanth (ed.), Danger! Educated Gypsy: Selected Essays. Hertfordshire: University of Hertfordshire Press. 47-53.

HETENYI, Ernest. 1972. Alexander Csoma de Koros, the Hungarian Bodhisattva. In: Bulletin of Tibetology 9(1): 34-41. Retrieved on 15/06/2019, from: http:// himalaya.socanth.cam.ac.uk/collections/journals/bot/pdf/bot_09_01_03.pdf.

KELÉNYI, Béla. 2012. A nyugati bódhiszattvától az örök vándorig: Csorba Géza Csoma-szobrai. Keletkutatás (2): 5-24. Retrieved on: 10/07/2019, from: http:// korosicsomatarsasag.hu/wp-content/uploads/2018/01/Keletkutatas_2012osz.pdf.

KOSZTOLÁNYI, Dezső. 1926. R. Tagore. Nyugat XI(22). Retrieved on: 10/07/2019, from: https://epa.oszk.hu/00000/00022/00407/index.html.

LAKATOS, Dóra. 2008. Indiai cigányok, avagy életre kelt európai „cigány mítoszok” Indiában. Világosság XLIX(5): 37-48.

MAGYAR KÖZLÖNY. 1991/82. 1766. Retrieved on: 19.09.2019, from: https:// adtplus.arcanum.hu/en/view/MagyarKozlony_1991_059-112/?query $=\mathrm{G} \% \mathrm{C} 3 \%$ B6ncz $\% 20$ Rahman $\% 20 \& p g=675 \&$ layout $=$ s.

MAJOR, István-KALMÁR, George. 1983. India and Hungary: Decades of Cooperation. New Delhi: Sterling Publishers Private.

MIKLÓS, Pál. 1999. Tunhuang és Stein Aurél. Ezredvég IX(10). Retrieved on: 10/09/2019, from: http://ezredveg.vasaros.com/html/1999_10/99104.htm\#mp.

NAGY, Miklós Mihály. 1997. Julianus barát. Magyar Szemle Új folyam VI(5-6). Retrived on: 20/09/2019, from: http://www.magyarszemle.hu/cikk/julianus_ barat.

NÉGYESI, Mária. 1987. A hindi nyelv és a mai indiai nyelvek oktatása Magyarországon. In: Bethlenfalvy, Géza-Puskás, Ildikó (eds), India magyar szemmel. Budapest: Indiai Nagykövetség. 70-72.

ORSÓS, Kata. 2011. Tagore és Gandhi öröksége ma is él. Interjú India nagykövetével, Guari Shankar Gupta úrral. Barátság 18(5): 24-25.

RAVASZ, László. 1926. Rabindranath Tagore. Református Szemle XXXV(10). Retrieved on: 10/07/2019, from: https://adtplus.arcanum.hu/en/view/Protest 
ansSzemle_1926/?query=rabindranath\%20tagore \%20magyarorsz\%C3\%A1go $\mathrm{n} \& \mathrm{pg}=675 \&$ layout $=\mathrm{s}$.

SÁNDOR, Zsuzsanna. 2008. Mentőakció. Bethelnfalvy Géza Indiáról és '56-ról. 168 óra XX(43): 22-23.

SANGHASEN, Singh. 1992. The Evaluation of Csoma de Körös's Researches in Tibeto-Buddhism. In: Satinder Kumar, Vij-Lázár, Imre (eds), Alexander Csoma de Körös (1784-1842). Pioneer of Oriental Studies in Hungary. New Delhi: Department of Slavonic and Finno-Ugrian Studies, University of Delhi and Hungarian Information and Cultural Centre. 9-27.

SELVARAJAN, Yesudian-HAICK, Erzsébet. 1994. Jóga és sport. Hammelburg: Drei Eichen Verlag. Retrived on: 21/09/2019, from: https://terebess.hu/ keletkultinfo/lexikon/Selvarajan-Yesudian-Sport-es-joga.pdf.

STEPANIĆ, Gorana. 2011. Creating a Value-Added Text: Descriptio peregrinationis Georgii Huszthii. Systasis. E-списание на Здружението на класични филолози “Антика” 18. Retrieved on: 21/09/2019, from: http://www. systasis.org/pdfs/systasis_18_3.pdf.

TÖTTÖSSY, Csaba. 1987. Az Indoeurópai Nyelvtudományi Tanszék története és a tanszéken folyó szanszkritológiai tudományos és oktató munka. In: Bethlenfalvy, Géza-Puskás, Ildikó (eds), India magyar szemmel. Budapest: Indiai Nagykövetség. 62-69.

VIDA, István. 1994. Rahman budapesti indiai ügyvivő beszámolói 1956. november-decemberi napokról. Múltunk 39(1-2): 257-282.

1998. Levél Nehruhoz, India miniszterelnökéhez. História XX(1): 23-25.

WOJTILLA, Gyula. 1987. Rabindranath Tagore Magyarországon. In: Bethlenfalvy, Géza-Puskás, Ildikó (eds), India magyar szemmel. Budapest: Indiai Nagykövetség. 26-29. 